\title{
NOTES ON SYNTOMIDAE (AMATIDAE) WITH DESCRIPTIONS OF NEW SPECIES.
}

\author{
By LORD ROTHSCHILD, F.R.S., Ph.D.
}

\begin{abstract}
$\mathrm{W}$
HEN I first arranged the Syntomidae in the Tring Museum I confined myself to the description of the large number of new species in the collection and did not publish any critical observations. In this paper, written while incorporating the large accessions received since 1912, I propose to draw attention to a few errors in nomenclature, etc., as well as describe some new forms. I will begin with the American groups.
\end{abstract}

\section{Orcynia calcarata (Walk.).}

The Rev. A. Miles Moss has eaptured and brought home several specimens of a large burrowing wasp which is evidently the model for this fine mimetic insect.

The resemblance is most apparent when both the moth and the wasp have the wing two-thirds folded.

\section{Pseudosphex ichneumonea Herr.-Sch.}

In volume I of the Catalogue of Lepidoptera Phalaenae Sir George Hampson has put as synonyms of $P$. ichneumonea, $P$. crabronis Druce and $P$. polybioides Burm., and the series in the British Museum when I was working on this group from 1909 to 1912 consisted of a number of examples of an insect agreeing with Druce's type of crabronis, also in the collection. When working on Pseudosphex lately I was puzzled by finding another species with yellow legs among my Tring series and also a third species near to noverca Schaus. I then looked up HerrichSchäffer's drawing and I found a figure agreeing in appearance with noverca Schaus and novercida Kaye and not in the remotest resembling crabronis Druce. I then looked up the British Museum series once more and found that Sir George Hampson had separated in the collection polybioides Burm. from the series placed under ichneumonea. Through the courtesy of Professor Kuntzen of the Berlin Museum I obtained excellent photographs of the type (or rather what was left of it) of Herrich-Schäffer's $P$. ichneumonea. Fortunately the wings are perfectly preserved. It was evident that this species was identical with either noverca or novercida. Mr. Kaye, when describing novercida, points out that vein 2 of the forewing arises just before the angle of the cell while in noverca this vein arises much before the angle of the cell. This is clearly visible on the photograph and proves that ichneumonea is the same as novercida Kaye. On examining crabronis Druce it is at once apparent that, besides its much larger size and different coloration, vein 2 of the forewing arises further from the angle of the cell than in ichneumonea = novercida and therefore is not only a different species from ichneumonea, but is the connecting link between the two sections. The correct nomenclature of the 4 species of Pseudosphex which come in question as regards Herrich-Schäffer's ichneumonea therefore is as follows: novercida Kaye = ichneumonea Herr.-Sh. ; polybioides Burm. and noverca Schaus are two 
quite distinct species both from true ichneumonea H.-S. and crabronis Druce and ichneumonea Hmpsn. must stand as crabronis Druce.

Dr. Draudt, in Seitz, Grossschmetterlinge der Erde, has followed Hampson in calling crabronis Druce and polybioides Burm. ichneumonea, and he figures what he calls the typical form, but if the figure is exact he has figured a fifth quite distinct species. In his text he says that "ichneumonea (= polybioides Burm.)," whereas Burmeister distinctly states his polybioides has yellow legs, whereas ichneumonea, crabronis, and noverca have black legs. The model of noverca, polybioides, and ichneumonea is the wasp Polybia nigra Sauss.

\section{Pseudosphex parallela sp. nov.}

o. Similar in colour and markings to ichneumonea and noverca, but vein 2 of forewing arises about halfway between the origin of this vein in the first and second of these species ; forecoxae white ; male valve edged with white ; underside of first segment whitish ; legs black, tarsi greyish rufous ; antennæ, thorax, and abdomen above black; forewing yellowish vitreous, in basal two-thirds whitish ; costal two-fifths densely clothed with smoky grey-brown scales ; hindwing yellowish vitreous.

Expanse $29 \mathrm{~mm}$.

Hab.-Santa Catherina, 2 ô ô.

\section{Pseudosphex polistes uniformis subsp. nov.}

o. Differs from $p$. polistes in being much darker on the body, less white beneath and the abdomen above being uniform dark brown without the light edges to the segments.

Hab.-1 ơ Cuyaba, Matto-Grosso, received from Paul Zobrys.

\section{Pseudosphex caurensis paraensis subsp. nov.}

o. Differs from $C$. caurensis below in the coxae being less white and the white band beyond the white border of the $\hat{o}$ valve being absent; the legs are paler yellow ; above the wings are paler, more uniform and yellowish ; abdomen more uniform, basal half darker chestnut, outer half more extended black.

Hab.-1 ô Para, ex coll. Miles Moss.

\section{Pseudosphex crabronis venezuelensis subsp. nov.}

Differs from $C$. crabronis in the strong rosy wash of the wings and in having a white dot on the $\hat{o}$ valve below.

Hab.-La Vuelta, Caura River, May 1903 (S. Klages coll.).

\section{Sphecosoma trinitatis Rothsch.}

The wasp model of this species is a species of Polybia near P. fasciata Sauss. collected by $\mathrm{S}$. Klages with the mimic.

\section{Sphecosoma curta sp. nov.}

․ Whole insect short and rounded.

Pectus and head yellow ; legs orange-red, hind tibia black behind; patagia yellow ; thorax black, with 4 yellow spots; antennae crimson, tipped with black; 
abdomen, basal segment yellow, rest crimson, second and third segments edged with black, rest edged with dull blue ; wings hyaline, bases yellow, narrow costal, terminal, and inner margins black, a subcostal band of crimson occupying central five-sixths of length of wing.

Expanse $28 \mathrm{~mm}$; forewing $12.5 \mathrm{~mm}$.

Hab.-Yahuarmayo, S.E. Peru, 1,200 feet, February-March 1912 (H. and C. Watkíns coll.).

\section{Sphecosoma deceptrix Hmpsn.} coll.).

The wasp model of this species is Polybia fasciata Sauss. (M. G. Palmer

\section{Sphecosoma flaveolum sp. nov.}

๙ิ. Palpi, forehead, legs below, and underside of abdomen bright yellow ; legs above pale orange; antennae brown-black, apical one-third chocolate brown; basal half of patagia yellow, apical half black; tegulae and thorax yellow streaked with black; abdomen, first 2 segments dusky yellow, rest black edged with yellow ; wings hyaline yellowish, dusky yellow at base and along inner margin of forewing, also between costa and subcosta of forewing.

Expanse $30 \mathrm{~mm}$. ; length of forewing $13 \mathrm{~mm}$.

Hab.-San Esteban, Venezuela, June 1909, Corosita, Caura River, June 1904, 3 ơ ô (S. M. Klages coll.).

The of from Corosita has the half of forewing above the median nervure much infuscated.

\section{Homoeocera multipuncta sp. nov.}

o. Pectus white; legs black, tibiae with indistinct white dots; abdomen and $\hat{o}$ valve black, valve underneath filled with a white flocky substance, abdomen with 6 white dots below ; antennae black; head and thorax velvety black with some metallic blue dots; white spots on the patagia, abdomen black with blue dots and three rows of white patches, one row has four white spots, other two three.

Wings hyaline with black bases, and black margins expanded at tornus of forewing and from tornus to vein 2 in hindwing.

Length of forewing $20 \mathrm{~mm}$. Expanse $46 \mathrm{~mm}$.

Hab.-Cuyaba, Matto Grosso (bought from Paul Zobrys), type; 2 ô ô Valencia, Venezuela ; 1 ô Buenavista, East Bolivia, 750 m., August 1906-April 1907 ; 1 ơ Santiago del Estero, East Bolivia, 1905-6 (J. Steinbach coll.).

\section{Homoeocera affinis sp. nov.}

․ Very similar to crassa Feld., but differs in the edges of the abdominal segments being narrower and white, NOT yellow, also the forewing has a triangular black apex which is entirely absent in crassa.

Length of forewing $17 \mathrm{~mm}$. Expanse $39 \mathrm{~mm}$.

Hab.-Merida, Venezuela (Briceno coll.).

\section{Autochloris consociata Walk.}

Sir George Hampson has placed this as a synonym of bijuncta Walk. but it is quite distinct, having no signs of the lateral white spots on the first abdominal 
segment and having the last THREE segments of the abdomen yellow (o) or red ( $\delta$ ), while bijuncta has only the last two so coloured.

\section{Autochloris flavosignata sp. nov.}

9. Nearest allied to caunus Cram., but differs in having white spots on the patagia and a large patch of dark buff with a sooty spot in it each side of the first abdominal segment.

Length of forewing $22 \mathrm{~mm}$. Expanse $50 \mathrm{~mm}$.

Hab.-British Guiana.

\section{Autochloris nigridior sp. nov.}

o. Allied to bijuncta, but smaller and the black borders to the wings wider ; differs also in having white shoulder-spots and a yellow frons; abdomen black with lateral white spots on first segment and blue ones on the second and third segments; the rest of abdomen black except the outer edges of abdominal tuft which are red.

Length of forewing $18 \mathrm{~mm}$. Expanse $40.5 \mathrm{~mm}$.

Hab.-Arouary (17/6/1887).

\section{Autochloris cuma Druce.}

Sir George Hampson, Dr. Draudt, and others have united with cuma a fairly common and widespread insect which has nothing to do with it. The latter when seen side by side with true cuma is strikingly larger, the black margins of the wings are much wider and the red patches of the abdomen in two of the three subspecies are much more conspicuous. This species has no name:

\section{Autochloris magnifica sp. nov.}

o. Allied closely to A. cuma, but much larger; differs from cuma in the very much wider black margins to the wings and in the other black markings being larger, in the underside of abdomen being entirely black except the anal valves, in the hindlegs being brown outside and golden yellow inside, in the two subdorsal patches on the first and second abdominal segments being buff not white, and in there being on the third to the seventh abdominal segments a row of dorso-lateral large wedge-shaped crimson patches, while in cuma the underside of the abdomen is crimson from the fourth to the seventh segments, the red colour running half up the side ; in both species the anal segment is red in the male.

o differs in the hindlegs being black and the centre of the anal segment being black.

Length of forewing, क cuma, $22 \mathrm{~mm}$. क人 magnifica, $27 \mathrm{~mm}$. Expanse q cuma, $50 \mathrm{~mm}$. ; magnifica ô $62 \mathrm{~mm}$., ㅇ $66 \mathrm{~mm}$.

Hab.-Santa Cruz de la Sierra, East Bolivia, 1905-6 (J. Steinbach coll.).

\section{Autochloris magnifica reducta subsp. nov.}

9. Differs from $m$. magnifica in the dorso-lateral buff patches on the first two abdominal segments being reduced to two buff dots and the red dorso-lateral patches on the third to seventh segments being reduced to lunulate spots. The anal valves are black with lateral red patches.

Hab.-Bolivia (Garlepp coll.). 
19. Autochloris magnifica rufipes subsp. nov.

o. Differs from $m$. magnifica in the hindleg having the whole tibia above scarlet, the tarsus pale brown and the femur black; it has the red dorso-lateral patches much larger and they run down on to the underside of the abdomen.

Hab.-Chanchamayo, Peru (A. Miles Moss coll.).

\section{Autochloris ectomelaena Hamps.}

ô. Similar to enagrus Cram., but wings have narrower black borders; the underside has broad white margin to the of valve and three bright orange bands to the last last three segments and laterally some indications of crimson intersegmental lines.

Length of forewing $20 \mathrm{~mm}$. Expanse $46 \mathrm{~mm}$.

Hab.-1 ô Itamarity, Narrows, Amazon (A. Miles Moss coll.), 2 oิ oิ Amazon (Felder coll.).

\section{Autochloris flavicosta sp. nov.}

․ Pectus black; antennae black; head and thorax black with metallic blue spots ; first segment of abdomen above whitish buff, rest black, outer half of seventh and anal segments and the margin of the preceding one deep orange, abdomen below black, edge of first segment white, anal segment orange; legs black; wings hyaline yellow, hyaline white below median vein of hindwing; costal area, and half inner area of forewing orange, apex broadly black, a narrow black terminal border from vein 4 to tornus, hindwing with narrow black border expanded in tornal area.

Length of forewing $18 \mathrm{~mm}$. Expanse $41 \mathrm{~mm}$.

Hab.-1 \& Paramba, Ecuador, January-May 1897 (W. Rosenberg coll.)

\section{Autochloris buchwaldi sp. nov.}

๙ิ. Pectus white; legs black with white spots on coxae; $\hat{\jmath}$ valve edged with a blue followed by a white line, abdomen black, anus yellow ; head metallic blue ; thorax black ; first abdominal segment orange buff, rest of abdomen black with blue intersegmental lines; anal segment and tuft orange buff with basal blue line ; forewing hyaline yellow, with black borders widely expanded at apex and tornus; subcostal area dirty yellow, two streaks at base of inner margin orange; hindwing hyaline white, with black borders widely expanded at tornus.

Length of forewing $18 \mathrm{~mm}$. Expanse $41 \mathrm{~mm}$.

Hab.-Quevedo, Ecuador (v. Buchwald coll.).

\section{Sarosa pseudohelotes sp. nov.}

$\widehat{0}$. Differs from helotes in having the $\hat{\sigma}$ valve on underside of base of abdomen black with white patch on each side of it, while this valve in helotes is entirely glistening white, in the tarsi being uniformly deep brown, not orange, and the patagia wholly black.

Length of forewing, oิ $22 \mathrm{~mm}$., o $26 \mathrm{~mm}$. Expanse, of $50 \mathrm{~mm}$., ㅇ $58 \mathrm{~mm}$.

Hab.-1 of type, 2 우, Sto. Domingo, Carabaya, 6,000 feet, July and December 1902 (dry and wet season) ; 2 ô ô La Oroya, Rio Inambari, S.E. Peru, 3,100 feet, March 1905 (wet season) (G. Ockenden coll.) ; 1 ô Paramba, Ecuador, 3,500 feet, May 1897 (dry season) (W. Rosenberg coll.). 


\section{Sarosa pseudohelotes intensior subsp. nov.}

今ㅇ․ Differ from $p$. helotes in the colour of the thorax and body being orange scarlet, not dark yellow, and in the dark borders of the wings being much wider, and the legs uniformly dark umber-brown.

Hab.-1 $1 \hat{\jmath}, 1$ \& Las Quiguas, near San Esteban, Venezuela (S. M. Klages coll.).

\section{Gymnelia flavicapilla sp. nov.}

§. Antennae black; pectus white; palpi yellow; frons yellow with blue spot; coxae inside buff, outside blue, tibiae inside creamy white, outside black, tarsi brown, inside golden ; $\hat{o}$ valve buff edged with white, rest of underside of abdomen buff; patagia black ringed with yellow and blue in centre; tegulae black, inner one-third orange ; thorax black with four blue spots ; abdomen black with blue spots and segments narrowly edged with dull orange, a wider buff edging on second segment; wings hyaline, apex on forewing and tornus on hindwing black, basal half of subcostal area vitreous ; a blue dot at base of forewing.

Length of forewing $14 \mathrm{~mm}$. Expanse $32 \mathrm{~mm}$.

Hab.-1 ô San Esteban, Venezuela, June 1909 (S. M. Klages coll.) ; $1 \hat{\jmath}$ Venezuela (Mocquerys coll.).

\section{Gymnelia felderi sp. nov.}

o. Frons, palpi and antennae black; pectus white, legs black with blue patches; $\hat{o}$ valve basal half black, apical half white; underside of abdomen black; vertex and patagia metallic greenish blue; thorax and tegulae black, with elongated greenish blue metallic spots; abdomen black with metallic greenish blue lateral spots, first three segments with yellow interspaces; wings hyaline yellow, apex and tornus black, basal half of costi-subcostal area orange yellow, apical half black.

Length of forewing $18 \mathrm{~mm}$. Expanse $42 \mathrm{~mm}$.

Hab.-Amazon (Felder coll.).

\section{Gymnelia peculiaris sp. nov.}

․ This species is unlike any other of the genus, but in coloration is nearest ethodaea Druce. Pectus, legs and underside of legs yellow; frons buff, palpi yellow with black tips; hindlegs with outer side of tibia and most of tarsus black; head black; patagia black with blue spots ; thorax black with blue spot and some orange marks; abdomen brick red, with black bands and subdorsal rows of metallic silvery blue spots; apical half of anal segment black; wings long and narrow, hyaline yellow, base orange, a black border all round, apex of forewing broadly black, an oval discocellular black patch; antennae black.

Length of forewing $15 \mathrm{~mm}$. Breadth of forewing $6 \mathrm{~mm}$. Expanse $33 \mathrm{~mm}$. Hab.-Mapiri, Bolivia.

\section{Gymnelia abdominalis sp. nov.}

․ Pectus, legs, head, antennae, thorax, and first four segments of abdomen black; tibiae marked with metallic blue; patagia, base of tegulae, base of forewing and lateral spots in basal half of abdomen metallic blue, outer half of abdomen bright orange-yellow; wings hyaline white, broadly bordered with 
black; apex of forewing (about outer fourth of wing) black; tornal area of hindwing largely black, with a vitreous spot.

Length of forewing $20 \mathrm{~mm}$. Expanse $45 \mathrm{~mm}$.

Hab.-Pebas, Amazon (M. de Mathan coll.).

There is in the Tring Museum a out of the Felder collection labelled "Cuba, Gundlach" ! ! ! which only differs in the legs and underside being sooty brown and the of valve having a whitish border.

\section{Mallodeta simplex sp. nov.}

o. Pectus white ; legs, antennae, head, thorax, and abdomen black; wings hyaline white ; forewing with narrow black margins expanded at apex and apex of vein 2 , subcostal area yellowish between costa and subcosta from base of wing to origin of vein 7 , base of both pairs of wings and narrow margin of hindwings black.

Length of forewing $17 \mathrm{~mm}$. Expanse $39 \mathrm{~mm}$.

Hab.-Villarica, Paraguay, April 1923 (F. Shade coll.).

\section{Pheia pseudelegans sp. nov.}

o. Nearest to elegans Druce, but patagia and tegulae entirely orange and the abdominal central spots are much smaller, basal fifth of subcostal area entirely orange, tarsi of fore and middle pairs of legs black, hind pair with tibiae black and tarsi white.

․ Similar but larger.

Length of forewing $\hat{o}$ (type) $14 \mathrm{~mm}$. Expanse $31 \mathrm{~mm}$.
우 $16 \mathrm{~mm}$.
$35 \mathrm{~mm}$.

Hab.-3 ธิ ô, 2 우 ( $\hat{o}$ type) Alto de Serra, Sao Paulo, February 1923April 1926 (R. Spitz coll.) ; 1 \% Ypiranga, Sao Paulo, April 1924 (R. Spitz coll.).

\section{Pheia insignis sp. nov.}

§. This is a very distinct species. Head and palpi black; pectus white, legs black, with a considerable quantity of white on inside of tarsi and tibiae ; o valve pure white; abdomen below black, frons and vertex with paired bluish white dots; antennae black, apical two-fifths white, with black tip; thorax, patagia, and tegulae brilliant orange ; abdomen brilliant orange, with median row of black dots, last two segments blackish steel blue ; wings hyaline, forewing base bright orange, rest of wing edged with black, expanding largely at apex and slightly at tornus, nervures black; hindwing with black margins and nervures.

Length of forewing $14 \mathrm{~mm}$. Expanse $31 \mathrm{~mm}$.

Hab.-1 ô Alto de Serra, Sao Paulo, March 1928 (R. Spitz coll.).

\section{Pheia fuscicorpus sp. nov.}

ㅇ. Closely allied to daphaena Hmpsn. and haemapleura Hmpsn. but differs at first sight by the entire lack of red colour. The body is entirely black; the patagia and a streak on the tegulae orange and some orange hairs at anus.

Size same as haemapleura.

Hab.-Minas Geraës, November 1929 (R. Spitz coll.). 


\section{Pheia simillima sp. nov.}

o. Differs from flavipicta Schaus in lacking the yellow streak in centre of inner margin of the forewing and in the absence of the central black and blue patch on the abdomen.

Size as in flavipicta.

Hab.-Cananche, Cundinamarca, July 1903 (M. de Mathan coll.), 3 ธิธิ.

\section{Loxophlebia semiaurantia sp. nov.}

๙ิ. Below head black; pectus, coxae, two spots on lower thorax, and $\hat{\jmath}$ valve white; legs black; abdomen black. Above frons white, vertex black; patagia and shoulders orange ; rest of thorax black; abdomen brown-black, first three segments orange, with brown-black patch on second and third; antennae brown-black. Wings hyaline, margins of forewing brown-black, widely expanded at apex and tornus; a discocellular brown-black patch joined to costa; hindwing with very narrow black border expanded at apex.

Length of forewing $10 \mathrm{~mm}$. Expanse $23 \mathrm{~mm}$.

Hab.-Para (Rev. A. Miles Moss coll.).

\section{Loxophlebia asmodeoides sp. nov.}

๙ิ. Differs from asmodeus Druce in the whole undersurface being yellow ; the antennae, thorax, and abdomen being deep olive-brown; an orange belt narrowly interrupted in the centre on third segment of abdomen ; anal segment of abdomen orange ; the dark margin of forewings not enlarged between veins 5 and 6 but from apex to vein 5 .

Length of forewing $11 \mathrm{~mm}$. Expanse $26 \mathrm{~mm}$.

Hab.-Bogota (Felder coll.).

\section{Loxophlebia roseipectus sp. nov.}

$\hat{\jmath}$. Pectus and forecoxae rose-coloured; legs pale brown; $\hat{o}$ valve white ; abdomen sooty brown; head and antennae black.

Above : patagia and tegulae golden yellow ; thorax black; abdomen black, two orange dorso-lateral spots on first segment of abdomen, and broad lateral yellow bands on rest of abdomen; anal tuft of abdomen yellow. Wings hyaline, basal three-fifths of subcosta and basal two-thirds of inner margin of forewing yellow ; margins of forewing black, widely expanded at apex and less so at tornus; hindwing with black border expanded at apex and reaching to tornus abdominal margin very narrowly yellow.

Length of forewing $12 \mathrm{~mm}$. Expanse $30 \mathrm{~mm}$.

Hab.-Lower Amazons, junction with Rio Madeira, February-March 1926 (Rev. A. Miles Moss coll.).

\section{Mesothen tigrina sp. nov.}

‥ Underside of thorax, abdomen, and legs bright orange; head black, frons white; antennae black; large black spot on thorax above; abdomen orange, regularly ringed with black. Wing shyaline, base of forewing orange, margins and veins black, the margins expanded at apex widely and tornus less 
widely; hindwing with margins very slightly expanded at apex, and at abdominal margin fringed with yellow hairs.

Length of forewing $14 \mathrm{~mm}$. Expanse $31 \mathrm{~mm}$.

Hab.-Caracas, Venezuela.

38. Mesothen ockendeni restricta subsp. nov.

$\hat{\jmath}$. . Differ from o. ockendeni Druce in having the body paler, more yellowish, and the black of the last two segments of the abdomen much reduced, being restricted to the anal segment alone dorsally and laterally.

Hab.-Merida, Venezuela (Briceno coll.).

Chrostosoma. In this genus considerable confusion exists owing to a number of authors having wrongly identified species figured by Cramer, Herrich-Schäffer, and Perty.

In the Catalogue, vol. i, p. 215, Sir George Hampson figures a female of fenestrina Butler as the male of decisa Walker and he unites under the name of haematica Perty zantes Herr.-Sch., fenestrina Butl., and chalconitis Druce; and under the name of echemus Stoll. dolens Walk. and stulta Herr.-Sch.

As regards these names, haematica Perty and zantes Herr.-Sch. are certainly synonymous, but Nот with fenestrina Butl., for they are identical with decisa Walk., which species must henceforth be known under the name of haematica Perty. Now with regard to the names echemus Stoll., dolens Walk., and stulta Herr.-Sch., the figures given by these three authors represent three widely different insects ; echemus Stoll I consider unrecognisable, but it is certainly not dolens Walk. ; and stulta Herr.-Sch., of which there are 9 specimens at Tring agreeing absolutely with the figure, is an entirely different insect. When I pointed out some of these facts to Sir George Hampson he saw at once that some of the names had been wrongly applied; but in the collection of the British Museum he applied the name of haematica Perty to an insect standing under the name of Saurita mediorubra Kaye, but here again I cannot agree, as the latter is a much duskier insect with a narrow dark border, whereas the figure of haematica Perty shows an insect with much paler and more translucent wings and a wider dark border exactly as in Chrostosoma decisa Walk. Beyond transferring haematica Perty to Saurita mediorubra Kaye in the drawers of the Museum, Sir George Hampson has not published anything correcting the nomenclature of these Chrostosoma, and Dr. Draudt, in Seitz Macrolepidoptera of the World, has followed Hampson's catalogue. The correct nomenclature is as follows :

Chrostosoma haematica Perty.

$=\quad$ zantes Herr.-Sch.

$=\quad$ decisa Walk.

Chrostosoma fenestrina Butl.

Chrostosoma dolens Walk.

Chrostosoma chalconitis Druce)

and echemus Stoll I consider at least for the present unrecognisable.

\section{Chrostosoma infuscatum sp. nov.}

o. Nearest to haematica Perty (decisa Walk.), differs in the entire absence of the blue metallic spots and the red basal spot on the abdomen. The wings 
are more vitreous, but the margins are much wider and more irregular and diffuse, giving the insect a smokier, dustier appearance; apical half of tegulae crimson.

Length of forewing $12 \mathrm{~mm}$. Expanse $27 \mathrm{~mm}$.

Hab. -5 ô ô Muzo, Rio Cantinero, Columbia, $400 \mathrm{~m} .=1,300$ feet $(\mathrm{A} . \mathrm{H}$. Fassl coll.) (type) ; 1 ô Cananche, Cundinamarca, July 1903 (M. de Malha. coll.) ; 1 ô Lita, Ecuador, 3,000 feet (Flemming coll.).

\section{Hyda (Chrysostola) excelsa sp. nov.}

․ Nearest to pelopia Druce, but unlike any other species of the genus. Below : pectus, thorax, and basal three-fifths of abdomen orange ; apical twofifths of abdomen black; coxae and tibiae of foreleg orange, basal half of tarsus whitish, outer half deep brown; middle leg, coxae, and tibiae orange, latter washed with brown, tarsi deep brown; hindleg, coxae, and femora orange, tibiae black, tarsi and end of tibiae white; head and antennae black. Above : thorax orange ; abdomen, basal half orange, anal half black, both sections powdered slightly with iridescent silvery seales. Wings hyaline, with slight yellowish gloss, nervures on basal half of forewing orange, on outer half black; a white dot at base of wing; base of wing, basal half of costal area, discocellular patch, and basal three-fifths of inner area deep orange ; outer half of costal area, a very large apical patch, and a large tornal patch sooty black; hindwing has an apical black tip, a fringe of black hair round wing ; all veins except outer three-quarters of $3,4,5$, and 6 orange.

Length of forewing $15.5 \mathrm{~mm}$. Expanse $34 \mathrm{~mm}$.

Hab.-Alto da Serra, Sao Paulo, March 1929 (R. Spitz coll.), 2 우. 


\section{$2 \mathrm{BHL}$ Biodiversity Heritage Library}

1931. "Notes on Syntomidae (Amatidae) with descriptions of new species." Novitates zoologicae : a journal of zoology in connection with the Tring Museum 37, 149-158. https://doi.org/10.5962/bhl.part.13259.

View This Item Online: https://www.biodiversitylibrary.org/item/22933

DOI: https://doi.org/10.5962/bhl.part.13259

Permalink: https://www.biodiversitylibrary.org/partpdf/13259

\section{Holding Institution}

Natural History Museum Library, London

\section{Sponsored by}

Natural History Museum Library, London

\section{Copyright \& Reuse}

Copyright Status: In copyright. Digitized with the permission of the rights holder.

Rights Holder: The Trustees of the Natural History Museum, London

License: http://creativecommons.org/licenses/by-nc-sa/4.0/

Rights: http://biodiversitylibrary.org/permissions

This document was created from content at the Biodiversity Heritage Library, the world's largest open access digital library for biodiversity literature and archives. Visit BHL at https://www.biodiversitylibrary.org. 